\title{
THE CULTURE OF AUTOBIOGRAPHY
}

\author{
$+$
}

Irvine Studies in the Humanities

Robert Folkenflik, General Editor 
CONTRIBUTORS

$$
+
$$

Lindon Barrett

Jerome Bruner

Robert Folkenflik

Barbara D. Metcalf

Genaro M. Padilla

Ronald Paulson

Linda H. Peterson

Roger J. Porter

John Sturrock

Julia Watson 


\section{THE C U L T UR E O F Autobiography}

Constructions of Self-Representation $+$

Edited by Robert Folkenflik 
Stanford University Press

Stanford, California

(C) 1993 by the Board of Trustees of the Leland Stanford Junior University

CIP data appear at the end of the book 